\title{
Research on Performance Evaluation of Beibu Gulf Port Development_-An Empirical Study of 11 Years of Data
}

\author{
Qiao Penliang ${ }^{1}$, Li Yue ${ }^{2}$ \\ ${ }^{1}$ Guangzhou College of Technology and Business;Professor, School of Economics and Management, Beibu Gulf University \\ ${ }^{2}$ Postgraduate, School of Economics and Management, Beibu Gulf University
}

\begin{abstract}
As an important infrastructure facility in our country, ports play a pivotal role in the water transportation industry. Whether the port logistics runs well or not has an important impact on the port customs, regional economy and even the national economy. Based on the three major ports in the Beibu Gulf Economic Zone (Beihai, Qinzhou, and Fangcheng Port), this paper constructs a comprehensive performance evaluation system for ports through a balanced score card, and then introduces data from Beibu Gulf ports, taking this as a case, and using the entropy method to calculate Develop the weights of various indicators in the comprehensive performance evaluation system, evaluate the comprehensive performance of the ports in the Beibu Gulf Economic Zone, and put forward suggestions for increasing the speed of infrastructure construction and focusing on port investment for the Beibu Gulf ports.
\end{abstract}

\section{Research background and literature review}

\subsection{Research background}

The Guangxi Beibu Gulf Economic Zone is an important platform for China's "Maritime Silk Road". With the signing of RCEP, ASEAN has risen to become my country's largest trading partner. As well as the "One Belt, One Road" plan, the Beibu Gulf port has become a southeastern region of China facing Southeast Asia. Direct and important ports have an important influence on trade exchanges in Southeast Asia and even international economic and political exchanges. In view of Guangxi's long-term economic underdevelopment, the Beibu Gulf port has a low starting level and slow development. After several years of development, the Beibu Gulf Port will complete a cargo throughput of 267 million tons in 2020, and complete a container volume of 5.3837 million TEUs, a growth rate of $37.6 \%$. But compared with many ports, the overall level is still low. The reason is that apart from policy guidance, talent introduction and technological level, the port's own construction and regional economic development have an important impact. How to enhance the competitiveness of the port, how to implement every small step of port development, and in which areas to focus on construction, are of practical significance to port construction. In addition to most of the external, force majeure, and short-term unsolvable effects of the development of things, this article builds a comprehensive port performance evaluation system based on the port itself and the Beibu Gulf Economic Zone closely related to the port. Weight-oriented, targeted and feasible countermeasures are put forward in order to improve the competitiveness of Beibu Gulf ports.

\subsection{Literature review}

From the research on port performance at home and abroad, the improvement of port competitiveness by experts and scholars mainly focuses on the impact of port logistics capabilities and regional economy on ports. Ma Yonggang (2007) builds a comprehensive and scientific evaluation index system of port logistics competitiveness through the internal mechanism of port logistics, and proposes targeted measures for port development [1]. Yan Ya (2013) analyzed the SWOT of Tianjin Port through the analysis matrix method, and used its own development advantages and special port logistics competitiveness to solve the huge gap between Tianjin Port and other large ports under the new situation and avoid homogeneous development [2]. Mo Jinju and Li Baimin (2018) used entropy method and TOPSIS method to analyze the relevant factors of port logistics development, and proposed development strategies to expand port logistics, strengthen infrastructure construction, and improve hinterland economic conditions for Beibu Gulf ports [3]. Wang Xiaoqin and Wang Qing (2019) believe that in the context of the "Belt and Road" initiative, port development must not only build infrastructure, but also introduce high-level and professional management talents for ports, rationally plan and differentiate port positioning and functions, also build a port logistics sharing platform[4]. Based on previous studies, this paper combines port logistics 
indicators and economic indicators in the Beibu Gulf Economic Zone, using balanced scorecards and entropy methods to construct a comprehensive port performance evaluation index system, and takes the Beibu Gulf port as an example,to make some suggestions for development.

\section{Research methods and performance indicator system construction}

\subsection{Research methods}

At this stage, there are many performance evaluation theories, mainly including scientific management theory, strategic management theory, value management theory, interest-related theory, contingency management theory, organizational behavior theory, incentive theory, etc. This article is based on the strategic management theory, using the balanced scorecard to evaluate the performance of Beibu Gulf ports. Balanced Score Card (Balanced Score Card), referred to as BSC, was first proposed by Robert Norton of the United States. In this article, apart from national policies, regional policies, technological level and other factors, only from the port's own strategic development, the balanced scorecard classifies port infrastructure and objective operating capabilities into input indicators, output indicators, hinterland economy and development potential. One level is the method and theory of evaluating the comprehensive performance of the port through the quantification of the four levels of indicators [5]. This method has the characteristics of being strategy-centric and "balanced" dimensions, which is conducive to the refinement of the port's strategic objectives for better implementation.

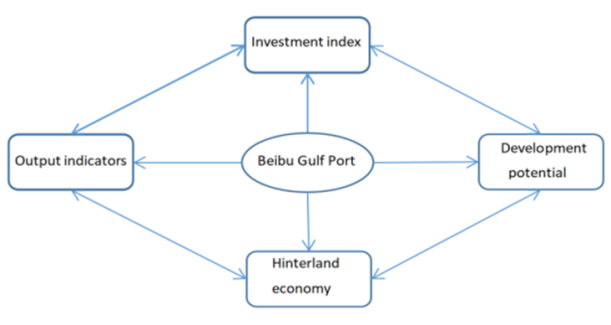

Fig.1. Balanced scorecard dimension relationship diagram

\subsection{Construction of port performance evaluation indicators}

This paper uses subjective screening method and objective screening method to screen performance evaluation indicators in four dimensions. Subjective screening methods include Delphi method, questionnaire survey method, and expert scoring method. Based on the opinions of experts, the four dimensions of evaluation indicators are determined and alternative indicators for subordinates. The objective screening method is to find the internal laws between the data through the use of mathematical statistics, mainly including principal component analysis and cluster analysis.

Through expert opinions and influencing factors generally concerned by domestic scholars, with reference to Ba Wenting [5], Guo Zhen [6] and other indicators of port logistics performance evaluation, according to the research objects in the article, the irrelevant indicators are adjusted and clustering is used. In the analysis method, 4 first-level indicators (dimensions) and 15 second-level indicators are set, and 15 indicators are all positive indicators, as shown in Table 1.

Table 1. Evaluation index and description

\begin{tabular}{|c|c|c|c|}
\hline Dimensions & Indicators & Unit & Indicator note \\
\hline \multirow{4}{*}{$\begin{array}{l}\text { Input } \\
\text { indicators }\end{array}$} & Port terminal berths & A & \multirow{4}{*}{$\begin{array}{l}\text { Beibu Gulf } \\
\text { Economic Zone }\end{array}$} \\
\hline & Pier length & $\mathrm{m}$ & \\
\hline & $\begin{array}{l}\text { Number of berths per } \\
10,000 \text {-ton terminal }\end{array}$ & A & \\
\hline & Total road mileage & Kilometres & \\
\hline \multirow{3}{*}{$\begin{array}{l}\text { Output } \\
\text { indicators }\end{array}$} & Port cargo throughput & 10,000 tons & $\begin{array}{c}\text { Beibu Gulf } \\
\text { Economic Zone }\end{array}$ \\
\hline & Cargo volume & 10,000 tons & \\
\hline & Gross regional product & Billions & $\begin{array}{c}\text { Beibu Gulf } \\
\text { Economic Zone }\end{array}$ \\
\hline \multirow{4}{*}{$\begin{array}{l}\text { hinterland } \\
\text { economy }\end{array}$} & $\begin{array}{c}\text { Gross imports and } \\
\text { exports }\end{array}$ & $\begin{array}{l}\text { Billions of } \\
\text { dollars }\end{array}$ & \\
\hline & $\begin{array}{l}\text { Actual utilization of } \\
\text { foreign capital }\end{array}$ & $\begin{array}{l}\text { Billions of } \\
\text { dollars }\end{array}$ & \\
\hline & GDP & Billions & \\
\hline & Economic Extroversion & $\%$ & $\begin{array}{l}\text { (total foreign trade/ } \\
\text { GDP)*100 per cent }\end{array}$ \\
\hline \multirow{4}{*}{$\begin{array}{l}\text { Developmen } \\
\text { t potential }\end{array}$} & $\begin{array}{l}\text { Regional GDP growth } \\
\text { rate }\end{array}$ & $\%$ & $\begin{array}{c}\text { Beibu Gulf } \\
\text { Economic Zone }\end{array}$ \\
\hline & $\begin{array}{l}\text { Cargo throughput } \\
\text { growth rate }\end{array}$ & $\%$ & \\
\hline & GDP growth rate & $\%$ & \\
\hline & $\begin{array}{l}\text { Growth rate of total } \\
\text { imports and exports }\end{array}$ & $\%$ & \\
\hline
\end{tabular}

\subsection{After determining the content of the index, use the entropy method to calculate the weight for each index.}

"Entropy" is a measure of uncertainty. The greater the amount of information, the smaller the uncertainty, and the smaller the amount of information, the greater the uncertainty. In social economic management, the degree of dispersion of a certain index can be judged according to the characteristics of entropy. In the performance evaluation of this article, the greater the degree of dispersion of the index, the greater the impact of the index on the comprehensive evaluation. The completeness of the index system is reflected in the difference and comprehensiveness of the index. The entropy method firstly processes the index data in a consistent manner, and in the subsequent dimensionless processing, eliminates the influence of 0 and negative values, making indicator data with different units and attributes having data meaning. Calculate the entropy of the processed data, basically determine the degree of dispersion of each index, and then calculate the weight of the index, then the performance evaluation index system is basically completed. 


\section{Case analysis of comprehensive port performance indicators-taking Beibu Gulf port as an example}

\subsection{Case introduction [7]}

The Beibu Gulf is located in the south of Guangxi, surrounded by land on three sides, and is a natural deep-water bay. It is an important port connecting China and ASEAN on the "Maritime Silk Road". In the early years, the development of Beibu Gulf ports was slow, and both the infrastructure of its own terminals, the sources of funds, cargo throughput, and the influence of the hinterland economy were all experiencing slow growth. Since the Beibu Gulf region was classified as an international economic cooperation zone, many national, provincial and municipal development policies have been superimposed over the years, but the development speed of the Beibu Gulf has stabilized.

This article takes the three main ports of Beibu Gulf (Beihai Port, Fangcheng Port, and Qinzhou Port) as the main research samples, and selects 11 years of Beibu Gulf from 2009 to 2019 as specific case data. The data comes from the "Guangxi Statistical Yearbook" and "China Statistical Yearbook". Among them, the number of berths, wharf lengths, and 10,000-ton-class berths of the three Beibu Gulf ports are missing data for 1-3 years.In the next calculation, in order to facilitate the calculation, the missing data will be compensated with the data of the most recent year's, as shown in Table 2.

Table 2. Raw data on the performance evaluation index for the Beibu Gulf port ,2009-2019

\begin{tabular}{|c|c|c|c|c|c|c|c|c|c|c|c|}
\hline Indicators & 2009 & 2010 & 2011 & 2012 & 2013 & 2014 & 2015 & 2016 & 2017 & 2018 & 2019 \\
\hline Port terminal berths & - & - & - & 177 & 177 & 179 & 183 & 187 & 190 & 190 & 192 \\
\hline Pier length & - & 24868 & 27136 & 31191 & 31496 & 34097 & 35937 & 37197 & 37953 & 38567 & 40096 \\
\hline Number of berths per 10,000 -ton terminal & - & - & - & 43 & 43 & 45 & 47 & 51 & 54 & 54 & 60 \\
\hline Total road mileage & 100491 & 101782 & 104889 & 107906 & 111384 & 114900 & 117993 & 120547 & 123259 & 125449 & 127819 \\
\hline Port cargo throughput & 9408 & 11923 & 15331 & 17438 & 18673 & 20189 & 20482 & 20392 & 21862 & 23986 & 25568 \\
\hline Cargo volume & 9738 & 12832 & 15813 & 19398 & 19549 & 22824 & 24741 & 26615 & 28405 & 30123 & 31881 \\
\hline Gross imports and exports & 142.06 & 177.06 & 233.31 & 294.74 & 328.37 & 405.53 & 512.62 & 478.97 & 572.10 & 623.38 & 682.02 \\
\hline Regional GDP (Beibu Gulf) & 2492.99 & 3042.75 & 3770.17 & 4268.59 & 4817.43 & 5448.72 & 5867.15 & 6488.07 & 7400.11 & 7228.99 & 7864.86 \\
\hline Actual utilization of foreign capital & 10.35 & 9.12 & 10.14 & 7.49 & 7.00 & 10.01 & 17.22 & 8.88 & 8.23 & 5.06 & 11.09 \\
\hline GDP( Guangxi) & 7112.91 & 8552.44 & 10299.94 & 11303.55 & 12448.36 & 13587.82 & 14797.80 & 16116.55 & 17790.68 & 19627.81 & 21237.14 \\
\hline Economic Extroversion (Guangxi) & 13.64 & 13.81 & 14.39 & 16.39 & 16.08 & 18.33 & 21.56 & 19.67 & 21.73 & 20.91 & 22.11 \\
\hline Cargo throughput growth rate & 16.31 & 26.73 & 28.58 & 13.74 & 7.08 & 8.12 & 1.45 & -0.44 & 7.21 & 9.72 & 6.60 \\
\hline GDP growth rate & 11.50 & 11.70 & 11.50 & 10.10 & 10.00 & 8.30 & 7.90 & 7.00 & 7.10 & 6.80 & 6.00 \\
\hline Regional GDP growth rate & 16.00 & 15.60 & 15.40 & 13.50 & 10.50 & 9.50 & 9.10 & 7.80 & 8.30 & 6.10 & 6.00 \\
\hline Growth rate of total imports and exports & 7.28 & 24.64 & 31.77 & 26.33 & 11.41 & 23.50 & 26.41 & -6.56 & 19.44 & 8.96 & 9.41 \\
\hline
\end{tabular}

In the table, the number of berths at the port in 2009 , 2010 , and 2011 were 177 , the length of the terminal was 24,868 meters in 2009 , and the number of berths at the 10,000-ton level was 43 in 2009, 2010, and 2011, respectively.

\subsection{Construction of port logistics performance index evaluation system based on entropy method}

3.2.1 The index attributes in the index system are all positive, as shown in Table 3

Table 3. Indicator attributes

\begin{tabular}{cccc}
\hline Dimensions & Indicators & $\begin{array}{c}\text { Indicator } \\
\text { attributes }\end{array}$ & Data attributes \\
\hline $\begin{array}{c}\text { Input } \\
\text { indicators }\end{array}$ & Port terminal berths & Positive & $\begin{array}{c}\text { Incomplete, } \\
\text { positive }\end{array}$ \\
Pier length & Positive & $\begin{array}{c}\text { Incomplete, } \\
\text { positive }\end{array}$ \\
\hline
\end{tabular}

\begin{tabular}{|c|c|c|c|}
\hline & $\begin{array}{l}\text { Number of berths per } \\
10,000 \text {-ton terminal }\end{array}$ & Positive & $\begin{array}{l}\text { Incomplete, } \\
\text { positive }\end{array}$ \\
\hline & Total road mileage & Positive & Positive \\
\hline \multirow{3}{*}{$\begin{array}{l}\text { Output } \\
\text { indicators }\end{array}$} & Port cargo throughput & Positive & Positive \\
\hline & Cargo volume & Positive & Positive \\
\hline & Gross regional product & Positive & Positive \\
\hline \multirow{4}{*}{$\begin{array}{l}\text { hinterland } \\
\text { economy }\end{array}$} & Gross imports and exports & Positive & Positive \\
\hline & $\begin{array}{l}\text { Actual utilization of } \\
\text { foreign capital }\end{array}$ & Positive & Positive \\
\hline & GDP & Positive & Positive \\
\hline & Economic Extroversion & Positive & Positive \\
\hline \multirow{4}{*}{$\begin{array}{c}\text { Development } \\
\text { potential }\end{array}$} & Regional GDP growth rate & Positive & $\begin{array}{c}\text { Positive/negative, } \\
\text { positive }\end{array}$ \\
\hline & $\begin{array}{l}\text { Cargo throughput growth } \\
\text { rate }\end{array}$ & Positive & Positive \\
\hline & GDP growth rate & Positive & Positive \\
\hline & $\begin{array}{l}\text { Growth rate of total } \\
\text { imports and exports }\end{array}$ & Positive & $\begin{array}{c}\text { Positive/negative, } \\
\text { positive }\end{array}$ \\
\hline
\end{tabular}




\subsubsection{Dimensionless treatment}

Among them, the 15 indicators are expressed as $\mathrm{X} 1, \mathrm{X} 2$, $\mathrm{X} 3, \mathrm{X} 4, \mathrm{X} 5, \mathrm{X} 6, \mathrm{X} 7, \mathrm{X} 8, \mathrm{X} 9, \mathrm{X} 10, \mathrm{X} 11, \mathrm{X} 12, \mathrm{X} 13, \mathrm{X} 14$, $\mathrm{X} 15$, and the years 2009-2019 are expressed as ABCDEFGHIJK, respectively. Ganghua treatment. In order for the data processing to be meaningful, negative values and zeros must be eliminated, so the dimensionless data is translated as a whole, that is $X_{i j}=X_{i j}+\alpha$, in order not to destroy the inherent law of the original data, the value $\alpha$ should be as small as possible. In this article, take $\alpha=0.002$. The results are shown in Table 4.

Table 4. Data after dimensionless, global translation

\begin{tabular}{|c|c|c|c|c|c|c|c|c|c|c|}
\hline A & B & $\mathrm{C}$ & D & $\mathrm{E}$ & $\mathrm{F}$ & G & $\mathrm{H}$ & I & $\mathrm{J}$ & K \\
\hline X1 .0020 & .0020 & .0020 & .00 & .00 & 53 & .4020 & 0.6687 & 7.8687 & .8687 & 1.0 \\
\hline X2 .0020 & .0020 & .1509 & .4172 & .4373 & .6081 & .7289 & 9.8116 & 6.8613 & .9016 & 1.0020 \\
\hline X3.0020 & .0020 & .0020 & .00 & .00 & .1196 & .2373 & 3.47 & 6.6 & .6 & 1.0020 \\
\hline X4..0020 & .0492 & .1629 & .27 & .4 & 93 & .6424 & 4.73 & & & .0020 \\
\hline X5 .0001 & .1561 & .3673 & .498 & .57 & .6685 & .6867 & 7.68 & .7722 & .90 & 1.0020 \\
\hline X6 .0020 & .1417 & .2764 & .43 & .44 & .5930 & .6796 & 5.76 & .8450 & .92 & 1.0020 \\
\hline X7. .0020 & .0668 & .1710 & .2848 & .34 & .4899 & .6883 & 3.6260 & .7984 & .8 & 1.0020 \\
\hline X8 .0020 & .1043 & .2398 & .3325 & .43 & .5522 & .6301 & $.745^{7}$ & .91 & .88 & 1.0020 \\
\hline X9.4370 & .3359 & .4198 & .2018 & .1615 & .4091 & 1.0020 & 0.316 & .2627. & .0020 & .4979 \\
\hline 10.0020 & .1039 & .2276 & .298 & .379 & .4604 & .5461 & I.639 & .75 & .888 & 1.0020 \\
\hline 11.0020 & .0221 & .0905 & .3267 & .2901. & .5557 & .9371 & 1.713 & .95 & .8603 & 1.0020 \\
\hline 12.5792 & .9383 & 1.0 & .49 & .26 & .2970 & .0671 & .0020 & .26 & .3521 & .2446 \\
\hline 13.9669 & 1.0020 & .9 & .72 & .70 & .4055 & 3 & .1 & .1 & .1 & .0020 \\
\hline 141.0020 & .9620 & .9420 & .7520 & .4520 . & .3520 & .3120 & .1820 & .2320 & .0120 & .0020 \\
\hline & & & & & & & & & & \\
\hline
\end{tabular}

3.2.3 Determining the weights of comprehensive performance evaluation indicators for Beibu Gulf ports

According to the dimensionless results of the Beibu Gulf port data from 2009 to 2019, and according to the formula for calculating the entropy value, the weight of each indicator is obtained, as shown in Table 5.

Table 5. Index Entropy, Difference Coefficient, Weight

\begin{tabular}{cccc}
\hline \multicolumn{4}{c}{ e entropyg of variance factors w of weights } \\
\hline $\mathrm{X} 1$ & 0.7011 & 0.2989 & 0.1501 \\
\hline $\mathrm{X} 2$ & 0.8798 & 0.1202 & 0.0604 \\
\hline $\mathrm{X} 3$ & 0.6858 & 0.3142 & 0.1578 \\
\hline $\mathrm{X} 4$ & 0.8840 & 0.1160 & 0.0583 \\
\hline $\mathrm{X} 5$ & 0.9270 & 0.0730 & 0.0366 \\
\hline $\mathrm{X} 6$ & 0.9158 & 0.0842 & 0.0423 \\
\hline $\mathrm{X} 7$ & 0.8872 & 0.1128 & 0.0566 \\
\hline & & &
\end{tabular}

\begin{tabular}{llll}
\hline $\mathrm{X} 8$ & 0.9035 & 0.0965 & 0.0485 \\
\hline $\mathrm{X} 9$ & 0.9074 & 0.0926 & 0.0465 \\
\hline $\mathrm{X} 10$ & 0.9003 & 0.0997 & 0.0501 \\
\hline $\mathrm{X} 11$ & 0.8630 & 0.1370 & 0.0688 \\
\hline $\mathrm{X} 12$ & 0.8768 & 0.1232 & 0.0619 \\
\hline $\mathrm{X} 13$ & 0.8827 & 0.1173 & 0.0589 \\
\hline $\mathrm{X} 14$ & 0.8569 & 0.1431 & 0.0719 \\
\hline $\mathrm{X} 15$ & 0.9375 & 0.0625 & 0.0314 \\
\hline
\end{tabular}

Based on Table 5 and the four dimensions of the balanced scorecard, the final evaluation index and weight are sorted out, as shown in Table 6.

Table 6. Performance Evaluation Index System for Beibu Gulf Port

\begin{tabular}{|c|c|c|c|}
\hline Dimensions & Weight & Indicators & $\begin{array}{c}\text { Weig } \\
\text { ht }\end{array}$ \\
\hline \multirow{4}{*}{ Input indicators } & \multirow{4}{*}{.4265} & Port terminal berths & .1501 \\
\hline & & Pier length & .0604 \\
\hline & & $\begin{array}{c}\text { Number of berths per } 10,000 \text {-ton } \\
\text { terminal }\end{array}$ & .1578 \\
\hline & & Total road mileage & .0583 \\
\hline \multirow{3}{*}{ Output indicators } & \multirow{3}{*}{.1356} & Port cargo throughput & .0366 \\
\hline & & Cargo volume & .0423 \\
\hline & & Gross regional product & .0566 \\
\hline \multirow{4}{*}{$\begin{array}{l}\text { hinterland } \\
\text { economy }\end{array}$} & \multirow{4}{*}{.2138} & Gross imports and exports & .0485 \\
\hline & & Actual utilization of foreign capital & .0465 \\
\hline & & GDP & .0501 \\
\hline & & Economic Extroversion & .0688 \\
\hline \multirow{4}{*}{$\begin{array}{l}\text { Development } \\
\text { potential }\end{array}$} & \multirow{4}{*}{.2241} & Regional GDP growth rate & .0619 \\
\hline & & Cargo throughput growth rate & .0589 \\
\hline & & GDP growth rate & .0719 \\
\hline & & $\begin{array}{c}\text { Growth rate of total imports and } \\
\text { exports }\end{array}$ & .0314 \\
\hline
\end{tabular}

Visualize the four dimensional weights, as shown in Figure 2

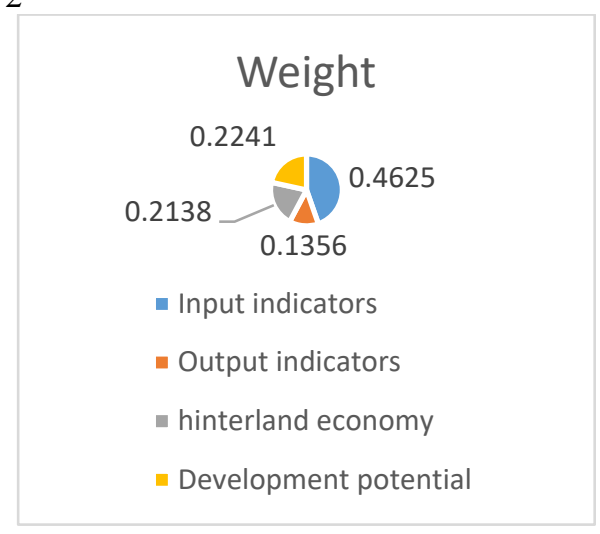

Fig.2. Dimension Weight Chart

\subsection{Evaluation results analysis}

From the above analysis, the most urgent thing for the 
Beibu Gulf port is to strengthen the investment in infrastructure. In terms of investment indicators, whether it is the number of berths or the length of the terminal, and even the main land transportation that is inseparable from the hinterland and port freight, highways have not seen rapid growth in 11 years. Without a solid infrastructure, no amount of preferential policies can be implemented, and benefits cannot be converted. Guangxi, as the most closely connected regional economy in the Beibu Gulf Economic Zone, complements the development of the port. The Beibu Gulf port has a geographical advantage in international trade with Southeast Asia, but not far from the Beibu Gulf is the leading Guangzhou Port in all aspects of the country. In contrast, Beibu Gulf ports should form alliances with neighboring large ports. In addition to avoiding the homogeneity of port competition, they should also expand the hinterland space and develop the hinterland economy. The indicators selected in the development potential dimension can truthfully reflect the data and indicators of port development. In the report and externally displayed, the growth potential is an important indicator reflecting the development status and future trends of the Beibu Gulf Economic Zone, which is conducive to the cooperation between the Beibu Gulf Economic Zone and enterprises, attracting funds, and attracting customers.

\section{Conclusion}

Strengthen the construction of Beibu Gulf port infrastructure, improve service quality, expand ports, increase berths, add more routes, speed up road construction, and provide conditions for multimodal transportation required for cargo to and into ports [8]. The ultimate goal of the construction of infrastructure is to improve the service level of logistics links for the purpose of port services. Only with perfect infrastructure can greatly enhance the competitiveness and attractiveness of the port's entry and exit, save cost for customers who choose the port, and provide a better service experience.

2. Promote the economic development of the hinterland, let the hinterland and the port rely on each other, and attract more domestic and foreign customers. In the development of the port, the economic conditions of the hinterland will directly affect the construction and operation of the port. Among the indicators of development potential, regional economic growth accounts for a high proportion, and there is an urgent need for stronger economic backstops. The Beibu Gulf port mainly relies on the Beibu Gulf Economic Zone, but in reality, it is not enough to rely solely on the hinterland near the port. The Beibu Gulf port should expand to the north. Consider building canals and other infrastructures through the economic land passing through the Pearl River and Xijiang River [9]. Together in series,only the more developed the hinterland, the greater the investment in the port and the stronger the attraction to the outside world, thus forming a virtuous circle.

3. Introduce scientific management and port technology, so that the port's input and output can be grasped with both hands. In the context of innovation as the driving force, introducing more scientific and efficient management methods and production methods is conducive to the efficient development of ports, efficient service to customers, efficient use of resources, and efficient conversion of economic benefits. Innovation means creativity, and creativity means more development potential. Only with potential can we input a steady stream of vitality for the port.

\section{Acknowledgments:}

Guangxi Science and Technology Department: China-Malaysia logistics technology talent exchange and innovation platform construction (Guike AD17195027)

\section{Reference}

1. Ma,Y.G.(2007) Research on Port Logistics Competitiveness Based on FCE-AHP .J. Economic Management ,22:78-83.

2. Maria.(2013) A Study on Evaluation of Logistics Competitiveness in Tianjin Port .D. Dalian Maritime University ,Master Thesis.

3. Mo,J.J., Li,B.L.(2018)The development strategy of Beibu Gulf ports under the background of "One Belt One Road".J.Business Economy,07:38-40+73.

4. Wang,X.Q., Wang,Q.(2019) Analysis on the Development of Port Logistics in Beibu Gulf of Guangxi under Belt and Road Initiative .J. Logistics Engineering and Management 41(01):4-5.

5. Ba, W.T. ,Zheng,Y. Wei,S.L. (2021)Research on Performance Evaluation of Port Logistics Based on Three-Phase DEA Model .J.Logistics Engineering and Management .43(02):46-48+45.

6. Guo,Z., Huang,J.b.(2020) Study on the Enhancement of Port Logistics Competitiveness Based on Factor Analysis — Taking Qinzhou Port as an example .J. Journal of Beibu Gulf University.35(02):58-63+79.

7. Chen,W.Y.(2019) Study on Comprehensive Performance Evaluation of Z Power Supply Branch of Jiangxi Power Grid .D.Donghua University of Technology.

8. Sun,R., Wang,Z.Y.(2013) Guo Mengyu. Comprehensive Evaluation of Port Competitiveness in China's Coastal Areas .J. Resource Development and Markets.29(08):809-813.

9. Tan,C.L., Yao,B.H.(2020) The Evaluation and Analysis of Shanghai Port Logistics Efficiency in the context of Yangtze River Delta Integration Strategy Based on the DEA-Malmquist Model.J $\backslash$ OL.Marine economy.1-15. https://doi.org/10.19426/j.cnki.cn12-1424/p.2020122 2.001 . 